\title{
Pengaruh Partisipasi Anggaran pada Senjangan Anggaran dengan Tight Budget dan Locus Of Control Sebagai Pemoderasi
}

\author{
Nyoman July Wiradiputra ${ }^{1}$ \\ Gayatri $^{2}$ \\ ${ }^{1}$ Fakultas Ekonomi dan Bisnis Universitas Udayana (Unud), Bali, Indonesia \\ email: nyomanjulywiradiputra@yahoo.com/telp: +62 81246173311 \\ ${ }^{2}$ Fakultas Ekonomi dan Bisnis Universitas Udayana (Unud), Bali, Indonesia
}

\begin{abstract}
ABSTRAK
Penelitian ini bertujuan untuk mengetahui pengaruh partisipasi anggaran pada senjangan anggaran dengan tight budget dan locus of control sebagai pemoderasi. Penelitian ini dilakukan pada 35 OPD di Kabupaten Badung. Metode penentuan sampel penelitian menggunakan nonprobability sampling dengan cara purposive sampling, dengan jumlah sampel sebanyak 105 responden. Pengumpulan data dilakukan dengan menggunakan kuesioner. Teknik analisis data yang digunakan untuk menguji hipotesis dalam penelitian ini adalah moderated regression analysis (MRA). Hasil analisis menunjukkan bahwa partisipasi anggaran berpengaruh positif pada senjangan anggaran. Hasil analisis MRA menunjukkan bahwa tight budget memperlemah pengaruh partisipasi anggaran pada senjangan anggaran, sedangkan locus of control memperkuat pengaruh partisipasi anggaran pada senjangan anggaran

Kata kunci: Partisipasi, Tight, Locus of Control, Senjangan, Anggaran
\end{abstract}

\section{ABSTRACT}

This study aims to determine the effect of budgetary participation on budget slack with tight budget and locus of control as moderator. This research was conducted at 35 OPD in Badung regency. The method of determining the research sample using nonprobability sampling by purposive sampling, with the number of samples of 105 respondents. The data were collected by using questionnaires. Data analysis techniques used to test the hypothesis in this study is moderated regression analysis (MRA). The results of the analysis show that budget participation has a positive effect on budgetary slack. The results of the MRA analysis show that the tight budget weakens the effect of budgetary participation on budget slack, while the locus of control strengthens the influence of budgetary participation on budgetary slack

Keywords: Participation, Tight, Locus of Control, Slack, Budget

\section{PENDAHULUAN}

Anggaran yaitu sarana yang dipergunakan untuk membicarakan rencana manajemen, mendistribusikan sumber daya, dan mengatur aktivitas operasional maupun strategis perusahaan (Pello, 2013). Fungsi anggaran yaitu sebagai alat pengelolaan bagi para pekerja dalam melaksanakan aktivitas organisasi yang bermanfaat. Partisipasi penyusunan anggaran merupakan proses dimana individu, 
yang kinerjanya dievaluasi dan memperoleh penghargaan berdasarkan pencapaian target anggaran, terlibat dan mempunyai pengaruh dalam penyusunan target anggaran (Brownell, 1982).

Pengganggaran partisipatif merupakan program yang bermanfaat untuk menyusun anggaran bagi semua anggota yang ada dalam organisasi ikut serta dalam menyusun anggaran (Yanti, 2016). Proses individu untuk mencapai target menggambarkan partisipasi menyusun anggaran dalam proses penganggaran serta apabila target dicapai akan mendapatkan penghargaan (Ariawan, 2015).

Anggaran yang akurat dan realistis akan memotivasi bawahan untuk memenuhi target yang dianggarkan (Otley, 1978). Salah satu gaya pengendalian anggaran yang ketat adalah pengevaluasian pegawai terutama pada kemampuan mereka mencapai anggaran yang ditetapkan dan pada saat pengevaluasian, para penyusun anggaran bertanggung jawab penuh terhadap hasil kerja seperti yang tercantum dalam anggaran (Astuti, 2017). Pengendalian anggaran yang ketat merupakan dampak penyelewengan perilaku yang berhubungan dengan kecurangan memenuhi target anggaran (Merchant, 1985).

Locus of Control adalah persepsi seseorang tentang sumber nasibnya yang disebabkan oleh dirinya atau faktor lain diluar dirinya. Partisipasi anggaran berpengaruh terhadap senjangan anggaran, pengaruh tersebut akan semakin kuat saat individu menganut locus of control (Tua Sinaga dan Hamka, 2013). Hasil penelitian yang dilakukan (Pello, 2014) menyatakan bahwa manajer atas diharapkan dapat memperhatikan pihak-pihak yang terlibat dalam proses penyusunan anggaran, diantaranya dengan cara memilih bawahan yang memiliki 
locus of control internal yang baik sehingga manajer menengah kebawah mampu mengendalikan dirinya untuk tidak melakukan senjangan anggaran.

Bugdetary slack adalah selisih antara anggaran yang ditargetkan dengan sesungguhnya (Pranata, 2017). Senjangan anggaran biasanya dilakukan dengan merendahkan pendapatan atau menaikkan biaya dari yang seharusnya, supaya anggaran yang ditargetkan mudah dicapai. Terjadinya senjangan anggaran dalam sektor publik bukan didasari karena adanya bonus maupun kenaikan gaji para pegawainya, melainkan karena adanya asas konservatif atau asas kehati-hatian (Pradani, 2016). Asas ini bertujuan untuk menjaga pengeluaran dan penerimaan dalam keadaan seimbang agar terhindar dari pengeluaran yang berlebihan.

Penelitian ini bertujuan untuk menguji kembali pengaruh partisipasi anggaran pada senjangan anggaran dengan tight budget dan locus of controlsebagai variabel pemoderasi di Pemerintah Daerah kabupaten Badung. Kabupaten Badung merupakan pusat kota organisasi sektor publik dengan Organisasi Perangkat Daerah (OPD) terbesar di Bali, sehingga memerlukan anggaran yang besar pula dalam pelaksanaan program-program kerja di masingmasing OPD (Biantara dan Putri, 2014). Pemilihan lokasi penelitian ini dikarenakan Kabupaten Badung mempunyai keahlian dalam bidang keuangan yang tertinggi di Provinsi Bali dibandingkan dengan kabupaten atau kota lainnya di Provinsi Bali.

Berdasarkan latar belakang yang telah diuraikan, maka yang dapat disimpulkan menjadi pokok permasalahan dalam penelitian ini adalah sebagai berikut : 1) Bagaimanakah pengaruh partisipasi anggaran pada senjangan 
anggaran di OPD di Kabupaten Badung?; 2) Apakah tight budget dapat memoderasi pengaruhpartisipasianggaran pada senjangan anggaran OPD di Kabupaten Badung?; 3) Apakah locus of control dapat memoderasi pengaruh partisipasi anggaran pada senjangan anggaran OPD di Kabupaten Badung?

Berdasarkan rumusan masalah di atas maka tujuan penelitian ini adalah sebagai berikut : 1) Untuk mengetahui pengaruh partisipasi anggaran pada senjangan anggaran pada OPD di Kabupaten Badung; 2) Untuk mengetahui pengaruh tight budget pada hubungan antara partisipasi anggaran dengan senjangan anggaran pada OPD di Kabupaten Badung; 3) Untuk mengetahui pengaruh locus of control pada hubungan antara partisipasi anggaran dengan senjangan anggaran pada OPD di Kabupaten Badung.

Penelitian ini diharapkan dapat memberikan kegunaan secara teoritis maupun secara praktis. Melalui penelitian ini penulis mengharapkan dapat memberikan manfaat bagi pihak-pihak yang berkepentingan meliputi; 1) Kegunaan teoritis, Penelitian ini diharapkan dapat menambah pengetahuan dan wawasan dalam menerapkan teori yang telah kita pelajari dengan fakta yang ada dan dalam rangka mengembangkan ilmu pengetahuan dunia pendidikan terutama mengenai bagaimana pengaruh partisipasi anggaran pada senjangan anggaran; 2) Kegunaan praktis, Penelitian ini diharapkan mampu menambah wawasan mengenai partisipasi anggaran, terutama pada senjangan anggaran dan mengetahui faktor-faktor apa saja yang memengaruhi senjangan anggaran seperti, partisipasi anggaran, tight budget dan locus of control. 
Agency Theory atau sering disebut teori keagenan diartikan sebagai hubungan kerjasama antara dua pihak, yaitu pihak pemilik perusahaan (pemerintah) dengan manajer perusahaan (manajemen) (Jensen \& Meckling, 1976). Pihak ketua OPD (principal) merupakan pihak yang memberikan wewenang dalam mengelola perusahaan kepada karyawan OPD (agent). Masalah keagenan (agency conflict) muncul karena adanya perbedaan kepentingan antara prinsipal dan agen dalam penyusunan anggaran. Permasalahan ini terjadi karena manajer cenderung melakukan moral hazard untuk memaksimalkan utilitasnya sehingga merugikan prinsipal (Widanaputra dan Mimba, 2014). Perbedaan kepentingan inilah yang akan menciptakan senjangan anggaran.

Theory of Planned Behavior (TPB) pertama kali dicetuskan oleh Ajzen pada tahun 1980 yang merupakan pengembangan dari Theory of Reasoned Action (TRA) yang telah dikembangkan terlebih dahulu oleh (Ajzen, 1991). Theory of Planned Behavior (TPB) menyatakan bahwa seseorang dapat bertindak berdasarkan intens atau niatnya hanya jika ia memiliki kontrol terhadap perilakunya.

Bugdetary slack adalah selisih antara anggaran yang ditargetkan dengan sesungguhnya (Pranata, 2017). Senjangan anggaran diartikan sebagai tindakan bawahan yang mengecilkan kapabilitas produktifnya ketika dia diberi kesempatan untuk menentukan standar kerjanya (Mark Young, 1985). Senjangan anggaran merupakan salah satu penyimpangan perilaku yang dilakukan oleh para penyusun anggaran (Saputra, 2016). 
Nyoman July Wiradiputra dan Gayatri. Pengaruh...

Pengendalian anggaran merupakan metode yang dibuat secara umum untuk menilai kemampuan pejabat penyusun anggaran dan berguna mengemukakan tujuan, strategi, proses perencanaan, dan bagaimana organisasi mendapatkan hasil yang dibutuhkan sementara menyelidiki pengeluaran (Hemsing, M. \& Baker, 2013). Tight Budget Control mungkin meningkat jika budgetary slack dapat diketahui sehingga dapat diperkirakan (Williamson, 1964). Keuntungan menggunakan pengendalian anggaran yang ketat adalah bahwa manajemen puncak mampu mendeteksi derivasi dari rencana dan mengambil tindakan dalam rangka meningkatkan efisiensi organisasi (Hemsing, M. and Baker, 2013).

Locus of control merupakan keyakinan individu terhadap suatu peristiwa yang dapat atau tidak dapat untuk mengendalikan peristiwa yang terjadi padanya. Locus of control diartikan sebagai tingkatan keyakinan seseorang terhadap keahlian mengontrol nasibnya sendiri (Sinaga, 2013). Jika orang tersebut tidak yakin terhadap dirinya, hal ini dapat menimbulkan indikasi gagalnya partisipasi anggaran yang akan berdampak pada penurunan kinerja dan rendahnya pencapaian sehingga berakibat mengakibatkan budgetary slack (Sinaga,2013). Locus of control didefinisikan sebagai sejauh mana seseorang merasakan hubungan kontijensi antara tindakan dan hasil yang mereka peroleh Tsui dan Gul (1996).

Hasil penelitian yang dilakukan oleh (Shuangcai \& Wenjun, 2009; Hartmann \& Maas, 2010; Zhang \& Liu, 2011; Tambunan dan Kurniawan, 2013; Miyati, 2014; Bakar, 2014; Maharani, 2015; Yanti, 2016; Basyir, 2016; Liandini, 
2017 yang menyatakan bahwa partisipasi anggaran berpengaruh positif terhadap senjangan anggaran maka semakin tinggi pula tingkat senjangan anggaran yang ditimbulkan. Budgetary slack dibuat oleh penyusun anggaran yang digunakan untuk mempermudah dalam menciptakan anggaran dan perilaku ini juga dipengaruhi oleh kontinuitas kedudukan individu sehingga menciptakan senjangan anggaran semakin tinggi (Widana dan Mimba, 2014). Bawahan mengartikan slack sebagai kebohongan sehingga diharapkan bawahan dapat mengurangi slack (Steven, 2002). Berdasarkan urain tersebut dapat disimpulkan hipotesis sebagai berikut:

$\mathrm{H}_{1}$ : Partisipasi anggaran berpengaruh positif pada senjangan anggaran.

Hasil penelitian yang menyatakan bahwa pengendalian anggaran yang ketat meningkatkan kemungkinan senjangan anggaran dapat diketahui sehingga dapat dibatasi (Williamson, 1964). Jika pengendalian anggaran ditingkatkan maka cenderung senjangan anggaran akan menurun (Dunk, 1993 \& Merchant, 1985). Metode tight budgetary control menjadi optimal dan lebih bermanfaat dalam memberikan informasi lebih lanjut kepada pimpinan dan informasi ini dapat menaikkan terjadinya senjangan anggaran tersebut dapat diketahui sehingga dapat diperkirakan dan para pembuat anggaran cenderung lebih terbatas untuk melakukan budgetary slack (Lau, 2001). Berdasarkan urain tersebut dapat disimpulkan hipotesis sebagai berikut:

$\mathrm{H}_{2}$ : Tight Budget memperlemah pengaruh partisipasi anggaran pada senjangan anggaran.

Penelitian Khusniah (2008) menguji analisis pengaruh antara Locus of Control terhadap hubungan antara partisipasi anggaran dengan senjangan 
Nyoman July Wiradiputra dan Gayatri. Pengaruh...

anggaran. Penelitian ini menunjukkan partisipasi anggaran berpengaruh positif terhadap senjangan anggaran serta interaksi antara partisipasi anggaran dengan locus of control memengaruhi timbulnya senjangan anggaran. Penelitian yang dilakukan oleh Adi dan Mardiasmo (2002) yang menunjukkan bahwa locus of control berpengaruh terhadap slack anggaran. Jika orang tersebut tidak memiliki keyakinan terhadap dirinya, hal ini dapat menimbulkan indikasi gagalnya partisipasi anggaran yang pada waktunya akan berdampak pada penurunan kinerja dan rendahnya pencapaian sehingga berakibat timbulnya budgetary slack (Sinaga,2013). Berdasarkan urain tersebut dapat disimpulkan hipotesis sebagai berikut:

$\mathrm{H}_{3}$ : Locus of Control memperkuat pengaruh partisipasi anggaran pada senjangan anggaran.

\section{METODE PENELITIAN}

Penelitian ini dilakukan pada Organisasi Perangkat Daerah (OPD) di Pemerintah Daerah Kabupaten Badung, terdapat 35 OPD yang digunakan dalam penelitian ini. Objek didalam penelitian ini adalah partisipasi anggaran $\left(\mathrm{X}_{1}\right)$ pada senjangan anggaran $(\mathrm{Y})$ yang dimoderasi oleh tight budget $\left(\mathrm{X}_{2}\right)$, danlocus of control $\left(\mathrm{X}_{3}\right)$ pada 35 OPD di Kabupaten Badung. Variabel terikat dalam penelitian ini adalah senjangan anggaran, variabel bebas dalam penelitian ini partisipasi anggaran, dan variabel moderasi dalam penelitian ini tight budget dan locus of control.

Partisipasi penyusunan anggaran $\left(\mathrm{X}_{1}\right)$ adalah proses dimana individu, yang kinerjanya dievaluasi dan memperoleh penghargaan berdasarkan pencapaian target anggaran, terlibat dan mempunyai pengaruh dalam penyusunan target anggaran. Partisipasi anggaran $\left(\mathrm{X}_{1}\right)$ diukur dengan instrument penelitian 
mempergunakan kuesioner yang diadopsi dari penelitian Ramadina (2013) yang telah dimodifikasi. Variabel tersebut diukur terdiri dari lima pernyataan dan skala likert empat poin sebagai alat ukurnya.

Tight Budget $\left(\mathrm{X}_{2}\right)$ adalah metode penggunaan anggaran dalam proses pengendalian yang ketat dengan membentuk standar target mengenai pendapatan dan pengeluaran serta pengamatan pemantauan kemampuan secara terus menerus dengan membedakan anggaran dengan aktualisasinya untuk penilaian kemampuan pejabat struktural yang terlibat dalam proses pembuatan anggaran. Tight Budget $\left(\mathrm{X}_{2}\right)$ diukur dengan instrument penelitian mempergunakan kuesioner yang diadopsi dari penelitian (Van der Stede, 2001) yang telah dimodifikasi. Tight Budget diukur dengan 5 indikator, yaitu: a) pemusatan untuk mencapai anggaran, b) tidak mudah menerima anggaran yang direvisi dalam setahun, c) pimpinan berfokus pada varian detail anggaran, d) tidak mudah memberi belas kasih atas penyelewengan dari target anggaran interim, e) pimpinan secara mendalam berperan serta terkait anggaran. Variabel tersebut diukur terdiri dari enam pernyataan dan skala likert empat poin sebagai alat ukurnya.

Locus of Control $\left(\mathrm{X}_{3}\right)$ merupakan kepribadian individu mengenai yakin atautidaknya dalam mengontrol peristiwa yang terjadi. Locus of Control $\left(\mathrm{X}_{3}\right)$ diukur dengan instrument penelitian mempergunakan kuesioner yang diadopsi dari penelitian Robbins (1998) yang telah dimodifikasi. Locus of Control diukur dengan 3 indikator, yaitu: a) kepercayaan akan adanya takdir, b) kepercayaan diri, c) usaha/kerja keras. Variabel tersebut diukur terdiri dari delapan pernyataan dan skala likert empat poin sebagai alat ukurnya. 
Nyoman July Wiradiputra dan Gayatri. Pengaruh...

Senjangan anggaran (Y) merupakan selisih antara anggaran yang ditargetkan dengan anggaran yang dicapai. Senjangan anggaran (Y) diukur dengan instrument penelitian mempergunakan kuesioner yang diadopsi dari penelitian (Lestiana \& Sari, 2017) yang telah dimodifikasi. Senjangan anggaran diukur dengan 8 indikator, yaitu: a) instansi terbaik yang dipilih untuk bekerja, b) manajer instansi bersedia menerima adanya kelonggaran, c) kelonggaran anggaran baik untuk melakukan sesuatu yang tidak dapat dibuktikan, d) standar anggaran mendorong produktivitas, e) anggaran untuk departemen dapat terlaksana, f) keterbatasan jumlah anggaran, g) target anggaran yang harus dicapai, h) sasaran dalam anggaran sangat susah dicapai. Variabel tersebut diukur terdiri dari delapan pernyataan dan skala likert empat poin sebagai alat ukurnya.

Populasi dalam penelitian ini adalah pada 35 OPD di Pemerintah Kabupaten Badung. Penelitian ini mengambil sampel dari seluruh Kepala OPD, Sekretaris OPD, Kepala Sub Bagian Keuangan dan Perencanaan OPD. Sampel OPD yang berjumlah sebanyak 105 orang responden. Penelitian ini menggunakan metode pengambilan sampel yaitu nonprobability sampling dengan cara purposive sampling. Penelitian ini menggunakan criteria sampel yaitu responden yang sudah menjabat minimal lebih dari satu tahun di OPD terkait dan ikut serta dalam menyusun, melaksanakan dan bertanggung jawab terhadap anggaran. Metode pengumpulan data dalam penelitian ini yaitu kuesioner.

Moderated regression analysis (MRA) dinyatakan dengan rumus:

$\mathrm{Y}=\alpha_{+} \beta_{1} \mathrm{X}_{1+} \beta_{2} \mathrm{X}_{2+} \beta_{3} \mathrm{X}_{3+} \beta_{4} \mathrm{X}_{1} \mathrm{X}_{2}+\beta_{5} \mathrm{X}_{1} \mathrm{X}_{3}+\mathrm{e}$

Keterangan:

$\mathrm{X}_{1} \quad=$ Partisipasi anggaran 
$\mathrm{X}_{2} \quad=$ Tight Budget

$\mathrm{X}_{3} \quad=$ Locus of Control

$\mathrm{Y} \quad=$ Senjangan anggaran

$\mathrm{X}_{1} \mathrm{X}_{2}=$ Interaksi antara partisipasi anggaran dan tight budget

$\mathrm{X}_{1} \mathrm{X}_{3}=$ Interaksi antara partisipasi anggaran dan locus of control

$\alpha \quad=$ Parameter konstanta

$\beta_{1}-\beta_{3}=$ Koefisien regresi berganda

e $\quad=$ Faktor lain yang mempengaruhi variabel $\mathrm{Y}$

Variabel moderasi dapat diklasifikasikan menjadi 4 jenis. Persamaan regresinya dapat dirumuskan sebagai berikut :

$\mathrm{Y}=\beta_{1} \mathrm{X}_{1}+\beta_{2} \mathrm{M}_{1}+\beta_{3} \mathrm{X}_{1} * \mathrm{M}$

\section{HASIL DAN PEMBAHASAN}

Penelitian ini menggunakan populasi yaitu pada OPD di Kabupaten Badung sebanyak 35 OPD. Berdasarkan metode nonprobability sampling dengan cara purposive sampling yang memenuhi kriteria dan dijadikan sampel sebanyak 105 pengurus di 35 OPD. bahwa kuesioner yang disebarkan ke responden sebanyak 105 kuesioner. Kuesioner yang tidak kembali sebanyak 10 kuesioner, kuesioner yang tidak lengkap sebanyak 5 kuesioner. Jadi kuesioner yang dapat digunakan yaitu sebanyak 90 kuesioner.

Analisis statistik deskriptif digunakan untuk memberikan gambaran atau deskripsi suatu yang dilihat dari nilai rata-rata (mean), nilai minimum, nilai maksimum, dan nilai standar deviasi dari data penelitian (Ghozali, 2016:19). Tabel 1 mengenai statistik deskriptif. 


\section{Tabel 1}

\section{Hasil Statistik Deskriptif}

\begin{tabular}{lccccl}
\hline Variabel & N & Min. & Max. & Mean & $\begin{array}{l}\text { Std. } \\
\text { Deviasi }\end{array}$ \\
\hline Partisipasi Anggaran $\left(\mathrm{X}_{1}\right)$ & 90 & 10 & 20 & 15,55 & 1,896 \\
Tight Budget $\left(\mathrm{X}_{2}\right)$ & 90 & 10 & 24 & 16,95 & 3,161 \\
Locus of Control $\left(\mathrm{X}_{3}\right)$ & 90 & 16 & 31 & 23,50 & 3,522 \\
Senjangan Anggaran $(\mathrm{Y})$ & 90 & 17 & 30 & 24,56 & 2,856 \\
\hline
\end{tabular}

Sumber: Data diolah, 2018

Berdasarkan hasil pengujian analisis statistik deskriptif pada Tabel 4.3 menunjukkan bahwa:

Variabel partisipasi anggaran $\left(\mathrm{X}_{1}\right)$ mempunyai hasil yaitu sebesar 10 nilai minimumnya, 20 nilai maksimumnya, 15,55 nilai meannya, dan 1,896 nilai standar deviasinya. Secara rata-rata jawaban responden mengarah ke nilai maksimum dengan nilai mean sebesar 15,55.

Variabel tight budget $\left(\mathrm{X}_{2}\right)$ mempunyai hasil yaitu sebesar 10 nilai minimumnya, 24 nilai maksimumnya, 16,95 nilai meannya, dan 3,161 nilai standar deviasinya. Secara rata-rata jawaban responden mengarah ke nilai maksimum dengan nilai mean sebesar 16,95.

Variabel locus of control $\left(\mathrm{X}_{3}\right)$ mempunyai hasil yaitu sebesar 16 nilai minimumnya, 31 nilai maksimumnya, 23,50 nilai meannya, dan 3,522 nilai standar deviasinya. Secara rata-rata jawaban responden mengarah ke nilai maksimum dengan nilai mean sebesar 23,50.

Variabel senjangan anggaran (Y) mempunyai hasil yaitu sebesar 17 nilai minimumnya, 30 nilai maksimumnya, 24,56 nilai meannya, dan 2,856 nilai standar deviasinya. Secara rata-rata jawaban responden mengarah ke nilai maksimum dengan nilai mean sebesar 24,56. 
ISSN: 2302-8556

E-Jurnal Akuntansi Universitas Udayana

Vol.25.1.Oktober (2018): 384-405

Uji normalitas, dilakukan dengan uji statistik onesample KolmogrofSmirnov dapat dilihat probabilitas signifikan terhadap variabel. Jika probabilitas signifikan di atas 0,05 maka variabel tersebut terdistribusi secara normal (Ghozali, 2016:157).

Tabel 2

Hasil Uji Normalitas

\begin{tabular}{cc}
\hline & Unstandardized Residual \\
$\mathrm{N}$ & 90 \\
\hline Kolmogorov-Smirnov Z & 0,473 \\
Asymp.Sig.(2-tailed) & 0,978 \\
\hline Sumber: Data diolah, 2018
\end{tabular}

Hasil Tabel dapat dilihat bahwa nilai Kolmogorov Sminarnov (K-S) sebesar 0,473, sedangkan nilai Asymp.Sig.(2-tailed) sebesar 0,978.

Uji heteroskedastisitas, dilakukan jika nilai signifikansinya di atas 0,05 maka tidak mengandung gejala heteroskedastisitas.

Tabel 3

Hasil Uji Heteroskedastisitas

\begin{tabular}{|c|c|c|c|c|c|}
\hline \multirow[t]{2}{*}{ Variabel } & \multicolumn{2}{|c|}{$\begin{array}{l}\text { Unstandardized } \\
\text { Coefficients }\end{array}$} & \multirow{2}{*}{$\begin{array}{c}\text { Standardized } \\
\text { Coefficients } \\
\text { Beta }\end{array}$} & \multirow[t]{2}{*}{$\mathbf{t}$} & \multirow[t]{2}{*}{ Sig. } \\
\hline & B & $\begin{array}{c}\text { Std. } \\
\text { Error }\end{array}$ & & & \\
\hline (Constant) & 0,386 & 0,031 & & 12,377 & 0,000 \\
\hline Partisipasi Anggaran $\left(\mathrm{X}_{1}\right)$ & $-0,045$ & 0,035 & $-0,158$ & $-1,280$ & 0,204 \\
\hline Tight Budget $\left(\mathrm{X}_{2}\right)$ & 0,056 & 0,039 & 0,195 & 1,430 & 0,157 \\
\hline Locus of Control $\left(\mathrm{X}_{3}\right)$ & $-0,028$ & 0,050 & $-0,090$ & $-0,564$ & 0,574 \\
\hline $\mathrm{X} 1 . \mathrm{X} 2$ & $-0,054$ & 0,038 & $-0,180$ & $-1,415$ & 0,161 \\
\hline $\mathrm{X} 1 . \mathrm{X} 3$ & $-0,003$ & 0,047 & $-0,011$ & $-0,067$ & 0,947 \\
\hline
\end{tabular}

Sumber: Data diolah, 2018

Pada Tabel dapat dilihat bahwa nilai Sig. dari variabel partisipasi anggaran, tight budget, locus of control, variabel interaksi X1.X2 dan variabel interaksi X1.X3, nilai significant yaitu 0,204;0,157;0,574; 0,161 dan 0,947. Jadi gejala heteroskedastisitas tidak terdapat pada model yang dibuat sudah melebihi nilai significant yaitu 0,05 . 
Penelitian yang diteliti memakai uji Moderated Regression Analysis (MRA). Hasil yang didapatkan ditunjukkan pada Tabel berikut :

Tabel 4

Hasil Moderated Regression Analysis (MRA)

\begin{tabular}{|c|c|c|c|c|c|c|}
\hline \multirow{2}{*}{ Variabel } & & \multicolumn{2}{|c|}{$\begin{array}{c}\text { Unstandardized } \\
\text { Coefficients }\end{array}$} & \multirow{2}{*}{$\begin{array}{c}\text { Standardized } \\
\text { Coefficients } \\
\text { Beta }\end{array}$} & \multirow{2}{*}{$\mathbf{t}$} & \multirow{2}{*}{ Sig. } \\
\hline & & B & $\begin{array}{l}\text { Std. } \\
\text { error }\end{array}$ & & & \\
\hline (constant) & & .006 & .055 & & .110 & .913 \\
\hline Partisipasi Anggaran $\left(\mathrm{X}_{1}\right)$ & & .349 & .061 & .353 & 5.679 & .000 \\
\hline Tight Budget $\left(\mathrm{X}_{2}\right)$ & & .186 & .069 & .186 & 2.712 & .008 \\
\hline Locus of Control $\left(\mathrm{X}_{3}\right)$ & & .214 & .088 & .194 & 2.424 & .018 \\
\hline ;i X1.X2 & & -.251 & .067 & -.239 & -3.731 & .000 \\
\hline ;i X1.X3 & & .225 & .082 & .234 & 2.745 & .007 \\
\hline $\mathrm{R}^{2}$ & : 0,760 & & & & & \\
\hline Adjusted $\mathrm{R}^{2}$ & : 0,746 & & & & & \\
\hline F Hitung & : 53,268 & & & & & \\
\hline Sig F & $: \quad 0,000$ & & & & & \\
\hline
\end{tabular}

Sumber: Data diolah, 2018

Berdasarkan hasil moderated regression analysis (MRA) seperti yang disajikan pada Tabel, maka persamaan strukturalnya adalah sebagai berikut :

$$
\begin{aligned}
& Y=\beta_{1} X_{1}+\beta_{2} X_{2}+\beta_{3} X_{3}+\beta_{4} X_{1} X_{2}+\beta_{5} X_{1} X_{3} \\
& Y=0,353 X_{1}+0,186 X_{2}+0,194 X_{3}-0,239 X_{1} X_{2}+0,234 X_{1} X_{3}
\end{aligned}
$$

Berdasarkan persamaan diatas, dapat dijelaskan hal-hal sebagai berikut. Nilai konstanta sebesar 0,006 menjelaskan jika nilai partisipasi anggaran $\left(\mathrm{X}_{1}\right)$, tight budget $\left(\mathrm{X}_{2}\right)$, locus of control $\left(\mathrm{X}_{3}\right)$, maka nilai senjangan anggaran $(\mathrm{Y})$ berarah positif.

Sebesar 0,349 nilai koefisien $\beta_{1}$ dimana bernilai positif menunjukkan bahwa apabila partisipasi anggaran $\left(\mathrm{X}_{1}\right)$ meningkat. Sebesar 0,186 nilai koefisien $\beta_{2}$. Nilai koefisien bernilai positif menunjukkan bahwa apabila tight budget $\left(\mathrm{X}_{2}\right)$ meningkat.Sebesar 0,214 nilai koefisien $\beta_{3}$. Nilai koefisien bernilai positif menunjukkan bahwa apabila locus of control $\left(\mathrm{X}_{3}\right)$ meningkat. 
Interaksi antara variabel partisipasi anggaran dengan tight budget menunjukkan nilai koefisien sebesar (-0,251) dengan nilai signifikansi $(0,000<0,05)$. Disimpulkan variabel tight budget memperlemah hubungan antara partisipasi anggaran dengan senjangan anggaran.

Interaksi antara variabel partisipasi anggaran dengan locus of control menunjukkan nilai koefisien sebesar 0,225 dengan nilai signifikansi $(0,007<$ 0,05). Disimpulkan variabel locus of control memperkuat hubungan antara partisipasi anggaran dengan senjangan anggaran.

Hasil analisis regresi linier berganda dalam Tabel menunjukkan Nilai determinasi (Adjusted $\mathrm{R}^{2}$ ) total sebesar 0,746 mempunyai arti bahwa sebesar $74,6 \%$ variasi partisipasi anggaran, tight budget, locus of control, variabel interaksi antara partisipasi anggaran dan tight budget dan variabel interaksi antara partisipasi anggaran dan locus of control memengaruhi senjangan anggaran, sedangkan sisanya sebesar $25,4 \%$ dijelaskan oleh faktor lain yang tidak dimasukkan ke dalam model.

Berdasarkan Uji Moderated Regression Analysis (MRA), maka dapat disimpulkan sebagai berikut :

Berdasarkan hasil analisis pengaruh Partisipasi Anggaran pada Senjangan Anggaran dengan Tight Budget sebagai variabel moderasi didapat sebesar 0,000 nilai signifikansinya dan sebesar $-0,239$ nilai koefisien regresinya. Nilai Signifikansi variabel moderasi $\left(\beta_{2}\right)$ Tight Budget sebesar 0,008 (significant) dan nilai signifikan variabel Interaksi antara partisipasi anggaran dan tight budget $\left(\beta_{4}\right)$ signifikan sebesar 0,000. Hasil analisis regresi moderasi menunjukkan bahwa nilai 
koefisien regresi Partisipasi Anggaran $\left(\beta_{1}\right)$ positif signifikan dan Interaksi antara partisipasi anggaran dengan tight budget $\left(\beta_{4}\right)$ negatif signifikan, maka variabel Tight Budget $\left(\mathrm{X}_{2}\right)$ merupakan variabel moderating yang memperlemah pengaruh Partisipasi Anggaran terhadap Senjangan Anggaran.

Berdasarkan hasil analisis pengaruh Partisipasi Anggaranpada Senjangan Anggaran dengan Locus of Control sebagai Variabel Moderasi didapat sebesar 0,007 nilai signifikansinya dan sebesar 0,234 nilai koefisien regresinya. Nilai Signifikansi variabel moderasi $\left(\beta_{3}\right)$ Locus of Control sebesar 0,018 (significant) dan nilai signifikan variabel Interaksi antara Partisipasi Anggaran dan Locus of Control $\left(\beta_{5}\right)$ signifikan sebesar 0,007. Hasil analisis regresi moderasi menunjukkan bahwa nilai koefisien regresi Partisipasi Anggaran $\left(\beta_{1}\right)$ positif signifikan dan Interaksi antara partisipasi anggaran dengan locus of control $\left(\beta_{5}\right)$ positif signifikan, maka variabel Locus of Control $\left(\mathrm{X}_{2}\right)$ merupakan variabel moderating yang memperkuat pengaruh Partisipasi Anggaran terhadap Senjangan Anggaran.

Pembahasan hasil penelitian untuk masing-masing hipotesis dapat dijabarkan sebagai berikut.

Hipotesis pertama $\left(\mathrm{H}_{1}\right)$ yang diteliti dalam penelitian ini adalah partisipasi anggaran berpengaruh positif pada senjangan anggaran. Berdasarkan hasil analisis pengaruh Partisipasi Anggaran pada Senjangan Anggaran didapat sebesar 0,000 yaitu nilai signifikansinya dan sebesar 5,679 yaitu nilai koefisien regresinya. Nilai Signifikansi $0,000<0,05$ menyatakan bahwa $\mathrm{H}_{0}$ ditolak dan $\mathrm{H}_{1}$ diterima. 
Simpulan yang didapat yaitu Partisipasi Anggaran berpengaruh positif dan signifikan pada Senjangan Anggaran.

Hipotesis kedua $\left(\mathrm{H}_{2}\right)$ yang diteliti dalam penelitian ini adalah tight budget memoderasi pengaruh partisipasi anggaran pada senjangan anggaran. Berdasarkan hasil analisis pengaruh Partisipasi Anggaran pada Senjangan Anggaran dengan Tight Budget sebagai Variabel Moderasi didapat sebesar 0,008 yaitu nilai signifikansinya dan sebesar 2,712. Nilai Signifikansi variabel moderasi $\left(\beta_{2}\right)$ Tight Budget sebesar 0,008 (significant) dan nilai signifikan variabel Interaksi antara Partisipasi Anggaran dan Tight Budget $\left(\beta_{4}\right)$ signifikan sebesar 0,000. Hasil analisis regresi moderasi menunjukkan bahwa nilai koefisien regresi Partisipasi Anggaran $\left(\beta_{1}\right)$ positif signifikan dan Interaksi antara partisipasi anggaran dengan tight budget $\left(\beta_{4}\right)$ negatif signifikan, maka variabel Tight Budget $\left(\mathrm{X}_{2}\right)$ merupakan variabel moderating yang memperlemah pengaruh Partisipasi Anggaran terhadap Senjangan Anggaran.

Hipotesis ketiga $\left(\mathrm{H}_{3}\right)$ yang diteliti dalam penelitian ini adalah locus of control memoderasi pengaruh partisipasi anggaran pada senjangan anggaran. Berdasarkan hasil analisis pengaruh Partisipasi Anggaran pada Senjangan Anggaran dengan Locus of Control sebagai Variabel Moderasi didapat sebesar 0,018 yaitu nilai signifikansinya dan sebesar 2,424. Nilai Signifikansi variabel moderasi $\left(\beta_{3}\right)$ Locus of Control sebesar 0,018 (significant) dan nilai signifikan variabel Interaksi antara Partisipasi Anggaran dan Locus of Control $\left(\beta_{5}\right)$ signifikan sebesar 0,007. Hasil analisis regresi moderasi menunjukkan bahwa nilai koefisien regresi Partisipasi Anggaran $\left(\beta_{1}\right)$ positif signifikan dan Interaksi antara partisipasi 
anggaran denganlocus of control $\left(\beta_{5}\right)$ positif signifikan, maka variabel Locus of Control $\left(\mathrm{X}_{2}\right)$ merupakan variabel moderating yang memperkuat pengaruh Partisipasi Anggaran terhadap Senjangan Anggaran.

\section{SIMPULAN}

Berdasarkan hasil penelitian mengenai pengaruh partisipasi anggaran pada senjangan anggaran dengan tight budget dan locus of control sebagai pemoderasi dapat disimpulkan sebagai berikut:

Hipotesis pertama mendapatkan hasil uji yang menyatakan bahwa partisipasi anggaran berpengaruh positif pada senjangan anggaran. Artinya semakin meningkatknya partisipasi dalam menyusun anggaran yang dilakukan oleh pejabat struktural OPD Kabupaten Badung maka akan cenderung meningkatkan terjadinya senjangan anggaran.

Hipotesis pertama mendapatkan hasil uji yang menyatakan bahwa tight budget memperlemah pengaruh partisipasi anggaran pada senjangan anggaran di OPD Kabupaten Badung. Hal ini disebabkan karena anggaran yang ketat akan menjadi tekanan bagi bawahan sehingga pejabat penyusun anggaran akan mencari peluang-peluang tertentu yang menguntungkan dan peluang inilah yang akan menyebabkan senjangan anggaran.

Hipotesis pertama mendapatkan hasil uji yang menyatakan bahwa locus of control memperkuat pengaruh partisipasi anggaran pada senjangan anggaran di OPD Kabupaten Badung. Hal ini disebabkan karena semakin rendahnya partisipasi anggaran yang terjadi dalam proses penyusunan anggaran yang di moderasi dengan locus of control para manajer yang relatif rendah, maka para 
manajer cenderung melonggarkan anggaran agar mudah mencapai target karena para manajer yang memiliki locus of control rendah atau eksternal tidak percaya pada keyakinannya sendiri, lebih menguntungkan harapan pada orang lain dan lebih banyak mencari dan memilih situasi yang menguntungkan. Ketika partisipasi anggaran terlalu tinggi akan cenderung menimbulkan perilaku yang menyimpang sehingga hal ini akan menyebabkan terjadinya senjangan anggaran.

Berdasarkan penelitian yang telah dilakukan dan kesimpulan diatas, hal tersebut diharapkan dapat diperbaiki dan dimodifikasi pada penelitian selanjutnya. Saran dari peneliti yang dapat diberikan adalah sebagai berikut :

Pihak pengelola atau karyawan pada OPD di Kabupaten Badung sebaiknya membuat hubungan kerjasama dengan bawahan dan meminta masukan kepada bawahan secara terbuka dalam proses menyusun anggaran sehingga senjangan anggaran dapat diantisipasi.

Penelitian ini tidak lepas dari keterbatasan antara lain proses pengumpulan data dalam penelitian ini mengalami kendala, yaitu terdapat Dinas/Badan tertentu yang menolak untuk mengisi kuesioner dengan alasan kesibukan dari responden yang bersangkutan. Penelitian selanjutnya disarankan menggunakan faktor lain yang dapat memengaruhi keputusan tanggung jawab terhadap penciptaan budgetary slack seperti kepercayaan, kompensasi, ketidakjelasan peran dan pengaruh sosial, seleksi dan pelatihan, pengendalian internal serta kejelasan sasaran anggaran, karena dalam penelitian ini menghasilkan Adjusted $R$ Square hanya menunjukkan 74,6\% yang berarti masih ada 25,4\% yang disebabkan oleh faktor lain. 
Penelitian ini mengambil objek OPD di Kabupaten Badung, disarankan pada penelitian selanjutnya menggunakan perusahaan lain sebagai sampel penelitian seperti hotel, bank dan wilayah penelitian lain yang cakupannya lebih luas.

\section{REFERENSI}

Ajzen, Icek. (1991). The Theory of Planned Behavior. Organizational Behavior and Human Decision Process. Vol. 50, pp. 179-211.

Ariawan, P., Wirakusuma, G., dan Ratnadi, D. (2015). Keadilan Prosedural dan Iklim Kerja Etis sebagai Pemoderasi Pengaruh Partisipasi Penganggaran pada Senjangan Anggaran (Studi Empiris Pada Pemerintah Kabupaten Tabanan). EJurnal Ekonomi Dan Bisnis Universitas Udayana, 7(4), 489-500.

Astuti, S. A. P. P., Wirama, D. G., dan Rasmini, N. K. (2017). Pengendalian Anggaran yang Ketat dan Orientasi Waktu sebagai Pemoderasi Pengaruh Anggaran Partisipatif pada Senjangan Anggaran. E-Jurnal Ekonomi Dan Bisnis Universitas Udayana, 6(2), 619-646.

Bakar, N. R. binti A. (2014). Impact of Organisational Factors on Budgetary Slack. E-Proceedings of the Conference on Management and Muamalah, (May), 26-27.

Biantara, A. A. A., dan Putri, I. A. M. A. D. (2014). Pengaruh Kejelasan Sasaran Anggaran, Etika, dan Kepercayaan Diri pada Senjangan Anggaran. E-Jurnal Akuntansi Universitas Udayana 9.2 (2014) : 385-391.

Brownell, P. (1980). Participation in the Budgeting Process: When It Works and When It Doesn't. Institute Of Technology, 39.

Brownell, P. (1982). “A Field Study Examination Of Budgetary Participation And Locus Of Control". The Accounting Review. Vol. 57, No. 4, Oktober 1982, hal: 766-777.

Dunk, A.S. (1993). The Effect of Budget Emphasis and Information Asymmetry on the Relation Between Budgetary Participation and Slack. The Accounting Review. 68, pp: 400-410.

Ghozali, Imam. (2016). Aplikasi Analisis Multivariative Dengan Program IBM SPSS 23. Semarang: Badan Penerbit Universitas Diponogoro.

Hartmann, F. G. H., \& Maas, V. S. (2010). Why business unit controllers create 
budget slack: Involvement in management, social pressure, and Machiavellianism. Behavioral Research in Accounting, 22(2), 27-49.

Hemsing, M. \& Baker, F. (2013). The Effects of Tight Budgetary Control on Managerial Behaviour in the Swedish Public Sector: Emphasizing Motivation, Commitment, Satisfaction and Stress. Master Of Business Administration Thesis, Karlstad Business School.

Jensen, M., \& Meckling, W. (1976). Theory of the firm: Managerial behavior, agency costs and ownership structure. Journal of Financial Economics, 3, 305-360.

Khusniah, Zumrotul. (2008). Analisis Pengaruh Antara Locus of Control, Komitmen Organisasi, dan Ketidakpastian Lingkungan, Terhadap Hubungan AntaraPartisipasi Anggaran Dengan SenjanganAnggaran (Studi Kasus Pada perusahaanmanufaktur di Gresik). Skripsi Program S-1. Universitas Muhammadiyah Gresik.

Lau, C. M., Kung, F.-H., Huang, C.-L., \& Cheng, C.-L. (2001). The Interactive Effects of Emphasis on Tight Budget Targets and Cost Control on Budgetary Performance. Pacific Accounting Review, 13(1), 59-84.

Lestiana, L., dan Sari, M. M. R. (2017). E-Jurnal Akuntansi Universitas Udayana Anggaran Fakultas Ekonomi dan Bisnis Universitas Udayana ( Unud ), Bali , Indonesia Fakultas Ekonomi dan Bisnis Universitas Udayana ( Unud ), Bali , Indonesia ABSTRAK Berdasarkan peraturan perundang-undangan negara $\mathrm{R}$, $18,847-873$.

Liandini, Vazria Ulfah dan Ni Gusti Putu Wirawati. (2017). Kemampuan Kecukupan Anggaran Memoderasi Pengaruh Partisipasi Anggaran pada Senjangan Anggaran. Jurnal Ekonomi Akuntansi. 18 (2), pp: 1-28.

Maharani, A. A. I. (2015). Pengaruh partisipasi penganggaran, asimetri informasi, dan budaya organisasi pada senjangan anggaran. E-Jurnal Akuntansi Universitas Udayana, 3, 770-785.

Mardiasmo, (2002). Akuntansi Sektor Publik. Yogyakarta: Andi.

Merchant, K. A. (1985). Budgeting and the propensity to create budgetary slack. Accounting, Organizations and Society, 10(2), 201-210.

Miyati. (2014). Pengaruh Partisipasi Anggaran Terhadap Budgetary Slack Dengan Pertimbangan Etika Sebagai Variabel Moderasi (Studi Empiris Pada Satuan Kerja Perangkat Daerah Kulon Progo). 
Otley, D.T. (1980). The Contigency Theory of Management Accounting Achievment and Prognosis. Accounting Organizations and Society, 5(4), pp: 413-428.

Pello, E. V. (2014). Pengaruh Asimetri Informasi dan Locus of Control pada Hubungan antara Penganggaran Partisipatif dengan Senjangan Anggaran. EJurnal Uniersitas Udayana, 6(2), 287-305.

Pradani, Komang Kartika Tri dan Ni Made Erawati. (2016). Pengaruh Partisipasi Penganggaran, Job Relevant Information, Kejelasan Sasaran Anggaran, dan Kapasitas Individu pada Senjangan Anggaran. E-Jurnal Akuntansi Universitas Udayana, 17(2): h: 852-884.

Ramadina, Westhi. (2013). Pengaruh Partisipasi Anggaran Terhadap Senjangan Anggaran Dengan Gaya Kepemimpinan Dan Budaya Organisasi Sebagai Variabel Pemoderasi (Studi Empiris Pada Satuan Kerja Perangkat Daerah Kota Payakumbuh). Artikel ilmiah. Program Studi Akuntansi Fakultas Ekonomi Universitas Negeri Padang. Hal 2-19.

Robbins, Stephen P dan Timothy A. (2015). Perilaku Organisasi. Edisi 16. Jakarta: Salemba Empat.

Shuangcai, Z., \& Wenjun, Z. (2009). Research on Present Situation of Budgetary Slack in Chinese Enterprise, 553-558.

Tsui, J.S.L. \& F.A. Gul. (1996). “Auditors' Behavior in an Audit Conflict Situation: A Research Note on the Role of Locus of Control and Ethical Reasoning". Accounting, Organizations and Society, Vol 21 No. 1

Tua Sinaga, M., dan Hamka Kampus Air Tawar Padang, J. (2013). Pengaruh Partisipasi Anggaran terhadap Senjangan Anggaran dengan Locus of Control dan Budaya Organisasi sebagai Variabel Pemoderasi (Studi Empiris pada SKPD Kota Pematang Siantar).

Van Der Stede, W. A. (2001). Measuring "tight budgetary control." Management Accounting Research, 12(1), 119-137.

Widanaputra, A.A.G.P \& Mimba, N.P.S.H. (2014). The Influence of Participative Budgeting on Budgetary Slack in Composing Local Governments Budget in Bali Province. Procedia - Social and Behavioral Sciences. Elsevier B.V., 164, pp: 391-396.

Zhang, S. C., \& Liu, G. Y. (2011). The control systems design of budgetary slack in Chinese enterprise. In Communications in Computer and Information Science (Vol. 232 CCIS, pp. 342-349). 